\title{
TAMARIX HOHENACKERI BUNGE, A NEW RECORD FOR THE FLORA OF MEXICO
}

\author{
José Luis Villar ${ }^{1,2}$, Ana Juan ${ }^{1}$ And María Ángeles Alonso ${ }^{1}$ \\ ${ }^{1}$ Universidad de Alicante, Instituto de la Biodiversidad-CIBIO, \\ P.O. Box 99, E-03080, Alicante, Spain. \\ ${ }^{2}$ Author for correspondence: jose.villar@ua.es
}

\begin{abstract}
Tamarix hohenackeri Bunge is reported here for the first time for the flora of Mexico. It also represents the first record for the American continent. This species, native from Asia, was collected along riversides of the river San Salvador (Ensenada, Baja California). A detailed morphological description of the newly reported taxon is provided, and the taxonomic treatment of $T$. hohenackeri is also discussed. As a result of this study, the presence of six species of the genus Tamarix is confirmed for Mexico, and a dichotomous key for the Tamarix species in Mexico is presented.
\end{abstract}

Key words: invasive flora, Mexico, Tamaricaceae, Tamarix, taxonomy.

\section{RESUMEN}

Se documenta por primera vez la presencia de Tamarix hohenackeri Bunge para la flora de México. Se trata, a su vez, de la primera cita para el continente americano. Esta especie, nativa de Asia, ha sido recolectada en los márgenes del río San Salvador (Ensenada, Baja California). Se aporta una descripción morfológica detallada del nuevo taxon citado y se discute, también, su estatus taxonómico. Como resultado del estudio, se indica la presencia de seis especies del género Tamarix y además se aporta una clave para la identificación de los representantes de Tamarix en México.

Palabras clave: flora invasora, México, Tamaricaceae, Tamarix, taxonomía. 


\section{INTRODUCTION}

Tamarix (Tamaricaceae) is mainly found in Asia, where two main centres of speciation and diversification have been reported (Baum, 1978). The first one would correspond to the Indo-Turanian area, where the oldest species, such as Tamarix ericoides Rottl., are mainly located. The second centre is basically placed around the Middle East, extending to the Eastern Mediterranean and Turkey. From both geographical areas, the genus migrated in a southerly and westerly direction towards Africa and Europe, and also in a northerly and easterly direction towards the cold deserts and the Pacific coast of Asia (Baum, 1978).

Most of the vegetative and reproductive morphological characters widely used for the taxonomical identification of the Tamarix taxa are rather variable among populations and even within a single individual. This heterogeneity has led to the recognition of a large number of taxa, increasing the taxonomic complexity of this genus. In fact, about 200 taxa have been described since Linnaeus (1753). There is no general consensus on the number of species or on their taxonomic treatment, and consequently between 54 and 90 species are currently recognized (Baum, 1978; Yang and Gaskin, 2007).

The genus Tamarix includes trees or shrubs 2-10 m high, branched and mainly glabrous, with a deep root system. Branches are green, reddish brown, dark brown or black. Leaves are alternate, sessile, scale-like, entire, sometimes decurrent, from slightly auriculate to amplexicaul or even vaginate, glabrous, mostly with salt-secreting glands. The inflorescences are racemose, simple or compound, often paniculately branched; and growing on branches of the previous or current year. Flowers are small, tetra or pentamerous and white to pink or purple. Bracts are entire, 1-8 mm length, from sessile to amplexicaul. Sepals vary from triangular-lanceolate to widely ovate; and their lobes are entire or slightly denticulate to dentate. Petals are deciduous or sometimes persistent after anthesis; ovate, elliptic or obovate, and sometimes with an ungiculate or cuneate base. The stamens are 4-15, with filaments inserted on the nectariferous disc. The ovary is mostly conic and with 3-4 styles. Numerous seeds are characterized by an apical sessile hairy pappus.

From an ecological point of view, Tamarix species are phreatophytes, which form dense groves growing in ravines, river banks and also in saline soils, mostly located in arid and semi-arid zones. The species have a remarkably high growth rate, reaching their habitual height in a short period of time (Velasco, 2008). Their salt and drought tolerance plus their fast growth, combined with very attractive blooms, have played a key role for the ornamental use of certain Tamarix species. Thus, 
they have also been cultivated to reduce desertification, as wind curtains, or also to stabilize soil in sand dunes (Melgarejo, 2000; Gaskin and Schaal, 2003; Natale et al., 2008).

By the 19th century, some Tamarix species were introduced to America and Oceania (Baum, 1967; Di Tomaso, 1998; Stromberg, 1998; Csurhes, 2008; Natale et al., 2008). In the United States, Tamarix species have been available in ornamental plant catalogues from the first half of the 19th century, and plant nurseries early offered shipment from the Atlantic coast to any state (Prince and Sons, 1837; Warner Harper, 1903). Since then, some Tamarix species have spread to North America and these plants are currently considered as the second worst plant invasion in the United States (Gaskin and Schaal, 2003). As a consequence, much effort has been expended to eradicate the Tamarix populations in the United States through national programmes (Anonymous, 2005). Both chemical and mechanical methods have been widely used (Sisneros, 1990), recently complemented by biological control programs (Milbrath et al., 2003).

The taxonomic and morphological complexity of this genus makes the correct identification of the invasive species remarkably difficult. In America, the morphological differentiation among closely similar species, such as Tamarix ramosissima Ledeb. and Tamarix chinensis Lour., has become notably problematic, due to their resemblance and also because of the frequent presence of hybrid forms, not previously reported in their native areas (Baum, 1967; Gaskin and Schaal, 2003; Gaskin and Kazmer, 2009).

In Mexico, Tamarix species were introduced through the United States and also due to commercial plantations (Glenn and Nagler, 2005). However, there are scarce publications focused on the genus Tamarix in Mexico. For the time being, five different species have been reported: Tamarix ramosissima Ledeb. (Tamarix pentandra Pall.), Tamarix chinensis Lour., Tamarix parviflora DC., Tamarix gallica L. and Tamarix aphylla (L.) Karst. (Villaseñor et al., 2002; Chambers and Hawkins, 2004; Rebman, 2007). T. ramosissima and T. chinensis are widely distributed in the western United States, with populations in all of the bordering states with Mexico. In the Mexican territory, these species are abundant in the Lower Colorado, Sonora and Chihuahua deserts, reaching Guaymas (Sonora) and the southern part of the Baja California peninsula (Zamora-Arroyo et al., 2001; Chambers and Hawkins, 2004; Glenn and Nagler, 2005; Rebman, 2007). In the case of Tamarix parviflora, it has been reported from California of the United States (Gaskin and Schaal, 2003), and some Mexican locations of Baja California and Baja California Sur (Anonymous, 2011). Populations of T. gallica have been mainly stated along the United 
States coast of the Gulf of Mexico (Gaskin and Schaal, 2003). There are some records of T. gallica for Mexico (Villaseñor et al., 2002), whose reference vouchers could not be reviewed for this study. Finally, T. aphylla shows a similar distribution to those of T. ramosissima and T. chinensis (Glenn and Nagler, 2005). Nevertheless, the distribution of this species in Mexico may be larger since other populations have been also identified in Baja California (pers. obs.) and in other southern locations such as "El Tule", near Oaxaca.

Field investigations and herbarium revisions carried out in Mexico identified samples that do not correspond to any of the formerly mentioned Tamarix taxa. Hence, a new record for the Mexican flora is given here.

\section{MATERIALS AND METHODS}

Plant material was collected in Baja California during the spring of 2010, and it is conserved at the herbarium ABH (University of Alicante, Spain). For the species identification and morphological characterization, different monographs of the genus Tamarix were consulted (Baum, 1978; Zohary, 1987; Yang and Gaskin, 2007). In addition, herbarium vouchers from BCMEX, G, K, MA, MO, PRC, PR, VAL and W (Thiers, 2011) were also examined. The abbreviations of author names follow those proposed by Brummitt and Powell (1992), amended by the IPNI (2012). Plant images were taken using Pentax K200D reflex digital camera with Pentax D FA Macro 100mm F2.8 WR.

\section{RESULTS AND DISCUSSION}

The species Tamarix hohenackeri is reported from Mexico for the first time, on the basis of plant material collected beside the San Salvador river (Ensenada, Baja California) (Fig. 1, Annex). This Tamarix population grows along both sides of the river, forming a long belt. Besides, herbaria reference works allowed us to find a voucher from Colorado (United States) in the Missouri herbarium (MO04808092), which also corresponds to T. hohenackeri (Annex). Therefore, this voucher, originally identified as T. parviflora, may represent the first record of the species for the American continent.

The following description of Tamarix hohenackeri is based on the observations of the herbarium material observed. 
Villar et al.: Tamarix hohenackeri, a new record for the flora of Mexico

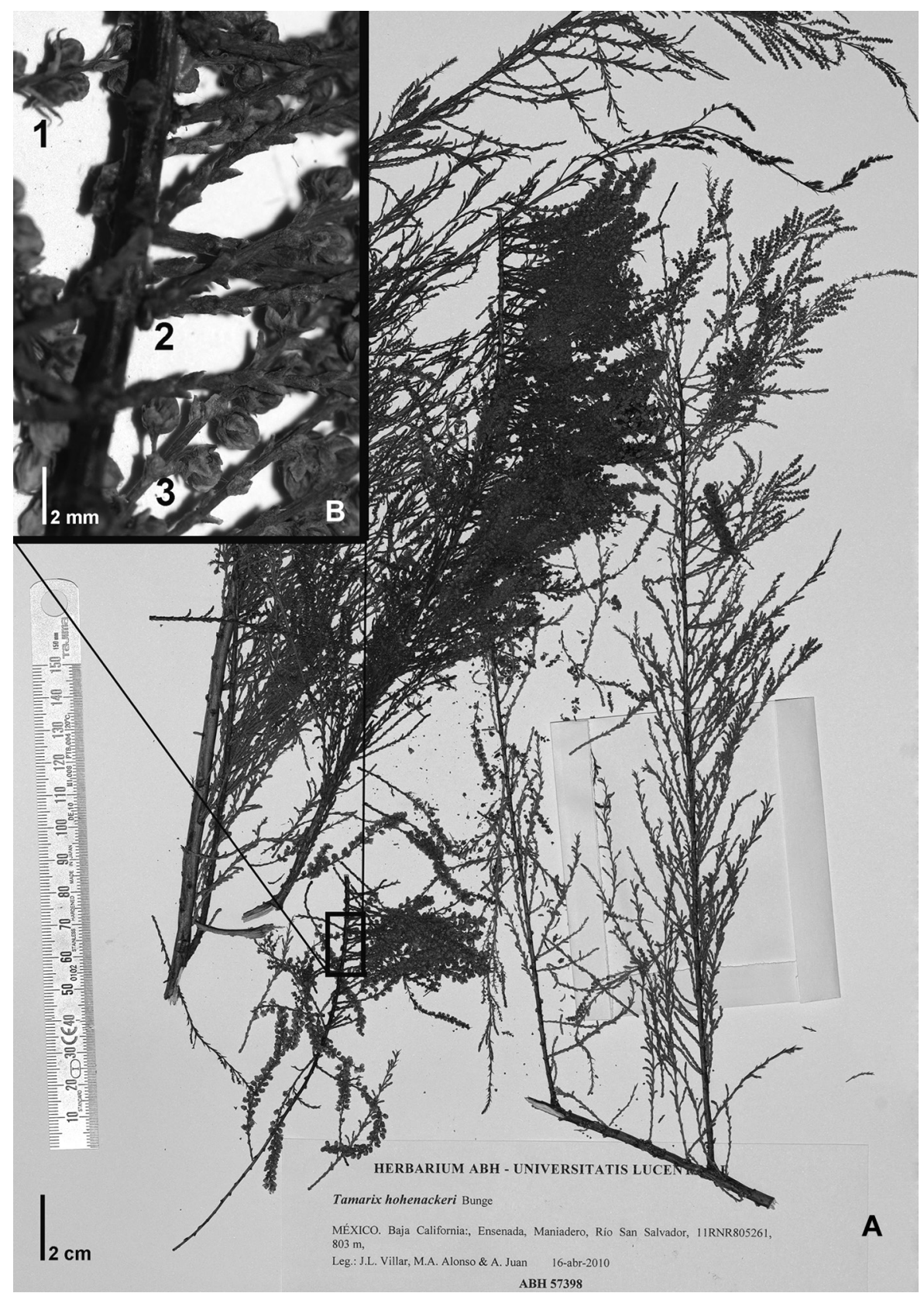

Fig. 1. Image of a specimen of $T$. hohenackeri from Mexico. A. general view of the herbarium voucher (ABH57398); B. detail of inflorescence; 1. apical bracts; 2. fasciculate racemes; 3. basal bracts. 
Tamarix hohenackeri Bunge, Tentamen, p. 44 (1852).

Tree, up to $5 \mathrm{~m}$ tall, entirely glabrous. Leaves ovate-triangular to lanceolate, acute, with a decurrent narrow base, sometimes slightly auriculate, 1.5-3.0 mm long. Inflorescences composed mostly of fasciculate arranged racemes, placed in spike-like panicles (not branched). Racemes 3.0-8.0(11.0) cm long, (5.0)5.5-6.0 mm wide, on short peduncles (3.0-10.0 mm long), naked or with a few bracts; rachis glabrous. Bracts of the racemes 1.5-3.0 mm long; lowermost bracts oblong and obtuse, wider and shorter than the narrowly triangular and acute uppermost bracts; bract length sub-equaling pedicel length at the lower part of the racemes to sub-equaling or slightly exceeding calyx length at the apex of the inflorescences. Pedicels 0.5$1.75(3.0) \mathrm{mm}$ long, usually longer in the lower part of the racemes, occasionally with 1-3 small secondary bracts. Sepals 5 (rarely 4), ovate, usually acute, with narrow hyaline margin, 1.0-1.3(1.5) $\mathrm{mm}$ long, 0.6-0.8 mm wide. Petals 5 , white or yellowish to pink, persistent, ovate-oblong to oblong, or widely elliptic, slightly emarginated, sometimes slightly keeled, 1.8-2.75 mm long, 1.0-2.0 mm wide. Stamens 5 (rarely 6), inserted between the lobes of the nectariferous disc; additional filaments inserted on the lobes. Anthers mostly not apiculate. Ovary always with 3 styles. Fruit 3-4 mm long.

The taxonomic placement of $T$. hohenackeri is not totally resolved, because this species was considered by Baum (1978) as a synonym of T. smyrnensis Bunge. This taxonomical treatment is especially relevant, since his monograph is a worldwide reference for the genus Tamarix. However, both taxa were originally described as two independent species (Bunge, 1852). Other authors as Yang and Gaskin (2007) and certain Asian botanists (e.g. N. Lachashvili, in sched. (W2008-21042); Belolipov and Haydarov, in sched. (MO6047301)] have also recognized T. hohenackeri as a species independent from $T$. smyrnensis. According to our data, there are enough morphological differences supporting the idea that the synonymization of T. hohenackeri into T. smyrnensis might not be fully appropriate. These morphological differences have not been only based on bibliographical data (Bunge, 1852; Yang and Gaskin, 2007), but also on the detailed study of herbarium vouchers of T. hohenackeri and T. smyrnensis, including the type material of both species (see Annex). The main vegetative and reproductive morphological differences between T. hohenackeri and T. smyrnensis are shown in Table 1. The most useful character to discriminate among these species corresponds to the fasciculate placement of racemes and their size, although the size and shape of bracts, sepals and petals are also essential for their accurate identification. 
Table 1. Morphological comparison between T. hohenackeri and T. smyrnensis.

\begin{tabular}{|c|c|c|}
\hline & T. hohenackeri Bunge & T. smyrnensis Bunge \\
\hline Raceme disposition & $\begin{array}{l}\text { in spike-shaped panicles, } \\
\text { solitary or fasciculate. Racemes } \\
\text { pedunculate and laxly flowered }\end{array}$ & $\begin{array}{l}\text { in panicles compound at their } \\
\text { base. Racemes sessile and } \\
\text { densely flowered }\end{array}$ \\
\hline Raceme length (mm) & $30.0-80.0$ & $8.5-25.0$ \\
\hline Bract shape & $\begin{array}{l}\text { short oblong (at lower part of } \\
\text { racemes) to narrowly triangular } \\
\text { (at upper part of racemes) }\end{array}$ & $\begin{array}{l}\text { narrow triangular-lanceolate, } \\
\text { acute }\end{array}$ \\
\hline Bract length (mm) & $1.5-3.0$ & $1.0-2.0(3.0)$ \\
\hline Bract-flower ratio & $\begin{array}{l}\text { equaling pedicel (at lower part } \\
\text { of racemes), almost equaling or } \\
\text { slightly exceeding calyx (at the } \\
\text { upper part of racemes) }\end{array}$ & $\begin{array}{l}\text { almost equaling or slightly } \\
\text { exceeding calyx (at lower part } \\
\text { of the racemes) }\end{array}$ \\
\hline Pedicel length (mm) & $0.5-1.75(3.0)$ & subsessile $(\leq 0.5)$ \\
\hline Sepal length (mm) & $1.0-1.3(1.5)$ & $0.7-1.0$ \\
\hline Sepal shape & $\begin{array}{l}\text { ovate, acute, with hyaline } \\
\text { margin }\end{array}$ & $\begin{array}{l}\text { ovate-lanceolate, acute, with } \\
\text { hyaline margin }\end{array}$ \\
\hline $\begin{array}{l}\text { Petal size: } \\
\text { length } \mathrm{x} \text { width }(\mathrm{mm})\end{array}$ & $1.8-2.75 \times 1.0-2.0$ & $1.2-1.9 \times 1.2-1.6$ \\
\hline Petal shape & $\begin{array}{l}\text { ovate-oblong to oblong, } \\
\text { sometimes elliptic, slightly } \\
\text { emarginated. Sometimes } \\
\text { slightly keeled }\end{array}$ & $\begin{array}{l}\text { suborbicular-elliptic, variable } \\
\text { from slightly ovate to slightly } \\
\text { obovate, with the lower half } \\
\text { clearly carinate-gibose }\end{array}$ \\
\hline
\end{tabular}

The native distribution area of Tamarix hohenackeri extends, at least, from the eastern Black Sea to Mongolia, central Asia and south-western Asia (Yang and Gaskin, 2007). There it is in contact with two closely related species, T. ramosissima and T. austromongolica Nakai. It is highly probable that $T$. hohenackeri was introduced in North America by the 19th or early 20th century for ornamental purposes, but was confused or intermixed with other similar ornamental species such as T. ramosissima. The distribution area of $T$. hohenackeri in North America could be wider than expected, since some additional vouchers of $T$. hohenackeri from the United States and Mexico could be misidentified as other species, such as T. chinensis, T. ramosissima and even T. parviflora.

With this new record, and including the previously available data (ZamoraArroyo et al., 2001; Villaseñor et al., 2002; Glenn and Nagler, 2005), six Tamarix species are part of the aloctonous flora of Mexico: Tamarix aphylla, T. gallica, T. 
parviflora, T. hohenackeri, T. ramosissima and T. chinensis, as well as the hybrids between the two latter species. Among them, T. aphylla, T. hohenackeri, T. ramosissima and T. chinensis were newly collected during the fieldwork conducted in April 2010, from different locations of Baja California (see Annex).

Below, a dichotomous key is presented for the six species of Tamarix reported for Mexico. The main morphological features are focused on leaf shape and insertion, raceme length and its disposition, bract shape, relative bract length, number, shape and size of the perianth sections and the site of insertion of the staminal filaments on the nectariferous disc.

Dichotomous key for the identification of Tamarix species in Mexico

1 Leaves vaginate T. aphylla

1 Leaves sessile with a narrow base, sometimes slightly auriculate at their lower

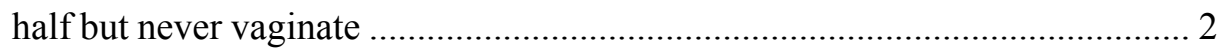

2 Flowers tetramerous ………….................................................. T. parviflora

2 Flowers pentamerous ....................................................................................... 3

3 Staminal filaments arising from the apex of the nectariferous disc lobes ..... T. gallica

3 Staminal filaments arising between the nectariferous disc lobes 4

4 Inflorescences with both solitary and fasciculate racemes (groups from 2 to 4) T. hohenackeri

4 Inflorescences with racemes always solitary 5

5 Racemes 5-7 mm wide. Bracts equal or slightly longer than the pedicel. Pedicels as long as sepals, at least the lowermost pedicels of the raceme T. chinensis

5 Racemes 3-5 mm wide. Bracts equal or slightly longer than the calyx. Pedicel length always shorter than that of the sepals ... T. ramosissima

\section{ACKNOWLEDGEMENTS}

We are grateful to Dr. José Delgadillo (University of Baja California, Mexico), for providing all the material and help to carry out our research in Mexico. We thank the curators of the herbaria mentioned in the text, especially to J. Solomon, E. Vitek, N. Fumeau and J. Stepanek who kindly helped us in the herbaria of 
Missouri, Vienna, Geneva and Prague, respectively. Mags Flaherty kindly revised the manuscript for the language corrections. This work has been supported by the BEST/2010/005 grant (Generalitat Valenciana, Spain), the projects CGL2008-05056 (Ministerio de Educación y Ciencia, Spain), ACIE10-01 and ACIE 11-01 (University of Alicante, Spain) and the FPU grant programme (Ministerio de Educación, Spain).

\section{LITERATURE CITED}

Anonymous. 2005. Program for biological control of saltcedar (Tamarix spp.) in thirteen States. Environmental Assessment. Animal and Plant Health Inspection Service, United States Department of Agriculture, Western Region. Fort Collins, USA. 56 pp. Anonymous. 2011. Tamarix parviflora, IEB 116120, 2 registers, CIBNOR-HCIB 11988, 2 registers. Unidad de Coordinación de Global Biodiversity Information Facility. Madrid, Spain. http://data.gbif.org/species/2874706/ accessed on 13-6-2011.

Baum, B. 1967. Introduced and naturalized tamarisks in the United States and Canada. Baileya 15: 19-25.

Baum, B. 1978. The genus Tamarix. Israel Academy of Sciences and Humanities. Jerusalem, Israel. 209 pp.

Brummitt, R. K. and C. E. Powell. 1992. Authors of plant names. Royal Botanic Gardens. Kew, UK. 732 pp.

Bunge, A. 1852. Tentamen generis Tamaricum species accuratius definiendi. Dorpati, Estonia. $83 \mathrm{pp}$.

Chambers, N. and T. O. Hawkins. 2004. Plantas invasoras del desierto sonorense: una guía de campo. Sonoran Institute, Environmental Education Exchange y National Birds and Wildlife Foundation. Tucson, USA. $60 \mathrm{pp}$.

Csurhes, S. 2008. Pest plant risk assessment: Athel pine Tamarix spp. The State of Queensland, Department of Primary Industries and Fisheries. Brisbane, Australia. $10 \mathrm{pp}$.

Di Tomaso, J. 1998. Impact, biology and ecology of saltcedar (Tamarix sp.) in southwestern United States. Weed Technol. 12: 326-336.

Gaskin, J. F. and D. J. Kazmer. 2009. Introgression between invasive saltcedars (Tamarix chinensis and T. ramosissima) in USA. Biol. Invasions 11: 1121-1130.

Gaskin, J. F. and B. Schaal. 2003. Molecular phylogenetic investigation of U.S. invasive Tamarix. Syst. Bot. 28(1): 86-95.

Glenn, E. P. and P. L. Nagler. 2005. Comparative ecophysiology of Tamarix ramosissima and native trees in western U.S. riparian zones. J. Arid Environ. 61: 419-446.

Linnaeus, C. 1753. Species plantarum, exhibentes plantas rite cognitas, ad genera relatas, cum differentiis specificis, nominibus trivialibus, synonymis selectis, locis natalibus, secundum sistema sexuale digestas. Vol. I. Holmiae Impensis Laurentii. Salvii. Stockholm, Sweden. 560 pp.

Melgarejo, P. 2000. Tratado de fruticultura para zonas áridas y semiáridas. Vol. 1. Ed. Mundi-Prensa. Madrid, Spain. 382 pp. 
Milbrath, L. R., C. J. DeLoach and A. E. Knutson. 2003. Initial results of biological control of saltcedar (Tamarix spp.) in the United States. Proceedings of the Symposium, Saltcedar and Water Resources in the West. Texas Cooperative Extension. San Angelo, USA. 135-141.

Natale, E. S., J. F. Gaskin, S. M. Zalba, M. Ceballos and H. E. Reinoso. 2008. Especies del género Tamarix (Tamaricaceae) invadiendo ambientes naturales en Argentina. Bol. Soc. Arg. Bot. 43(1-2): 137-145.

Prince, W. and Sons. 1837. Annual catalogue of trees and plants cultivated at the Linnean Botanic Garden and Nurseries. New York, USA. pp. 2-4, 50.

Rebman, J. P. (comp.). 2007. The flora of Cedros Island, Mexico. San Diego Natural History Museum, Biodiversity Research Center of the Californias Botany. San Diego, USA. www.bajaflora.org/Floras/CedrosIsland.htm (accessed 10-6-2011).

Sisneros, D. 1990. Vegetation management study: Lower Colorado River. Appendix II: Herbicide Analysis. USDI Bureau of Reclamation, Report. Denver, USA. 56 pp.

Stromberg, J. 1998. Dynamics of Fremont cottonwood (Populus fremontii) and saltcedar (Tamarix chinensis) populations along the San Pedro River, Arizona. J. Arid Environ. 40: 133-155.

The International Plant Names Index. 2012. Published on the Internet http://www.ipni.org (accessed 3-XII-2012).

Thiers, B. 2011. continuously updated. Index Herbariorum: A global directory of public herbaria and associated staff. New York Botanical Garden's Virtual Herbarium. http://sweetgum.nybg.org/ih/

Velasco, J. 2008. Manual para la restauración de riberas en la cuenca del río Segura. Confederación Hidrográfica del Segura. San Vicente del Raspeig, Spain. 227 pp.

Villaseñor, J. L., J. Rzedowski and F. J. Espinosa. 2002. In: Espinosa, F. J. Malezas introducidas en México. Universidad Nacional Autónoma de México, Centro de Investigaciones en Ecosistemas. Informe final SNIB-CONABIO proyecto No. U024. Morelia, México. 25 pp. http://www.conabio.gob.mx/institucion/proyectos/ resultados/InfU024.pdf (accessed 3-XII-2012).

Warner Harper, W. 1903. Andorra hand-book of trees and shrubs. Andorra Nurseries. Philadelphia, USA. pp. 5, 98.

Yang, Q. and J. Gaskin. 2007. Tamarix. In: Zhengyi, W. and P. H. Raven (eds.). Flora of China 13: Science Press, Beijing and Missouri Botanical Garden Press. St. Louis, USA. pp. 59-65.

Zamora-Arroyo, F., P. L. Nagler, M. Briggs, D. Radtke, H. Rodriguez, J. García, C. Valdés, A. Huete and E. P. Glenn. 2001. Regeneration of native trees in response to flood releases from the United States into the delta of the Colorado River, Mexico. J. Arid Environ. 49(1): 49-64.

Zohary, M. 1987. Tamarix L. Flora Palestina 2: 350-362. 
Villar et al.: Tamarix hohenackeri, a new record for the flora of Mexico

\section{ANNEX}

Selected material:

T. aphylla. MEXICO. Baja California: Mexicali, Laguna Salada, junto a carr. Tecate - Mexicali, 11SPS177042 (32³4'8,4" N-11544'46,1" W), 0 m, 18-4-2010, Leg. J.L. Villar, M.A. Alonso, A. Juan (ABH55929); Oaxaca: El Tule, 14QQP5286 (17²'53,7" N-96³8'1,6" W), 1560 m, 20-4-2010, Leg. A. Juan (ABH56707); Sonora: Región del Pinacate, rancho entre dunas cercanas a la estación de ferrocarril Gustavo Sotelo, 16-9-1980. Leg. M. Equihua, J. LópezPortillo, E, Ezcurra, Det. R.S. Felger (BCMEX005453).

T. chinensis. MEXICO. Baja California: Ensenada, carr. Ensenada - Maniadero, 11RNR350143 (31'45'49,2"N-116³7'49,4" W), 100 m, 15-4-2010,Leg.J.L. Villar,M.A. Alonso(ABH57396); Ensenada, carr. Ensenada - Maniadero, 11RNR350143 (31'45'49,2" N-116037'49,4" W), 100 m, 15-4-2010, Leg. J.L. Villar, M.A. Alonso (ABH57397); Ensenada, Estero Beach, carr. Ensenada - La Bufadora, 11RNR355088 (31 ${ }^{\circ} 42^{\prime} 50,5^{\prime \prime}$ N-116 $37^{\prime} 31,2^{\prime \prime}$ W), 0 m, 15-42010, Leg. J.L. Villar, M.A. Alonso (ABH57461); La Angostura, 11RNQ6475 (31'24'28,3" N-11619'36,2" W), 172 m, 24-4-2010, Leg. J.L. Villar, M.A. Alonso (ABH55928).

T. hohenackeri. ARMENIA. Syunik province, SSE Sisian, Between Darbas and Ltsen, 146-2007, Leg. M. Oganesian, Ter-Voskanyan, E. Vitek, Det. J.L. Villar (W2010-02963). REPUBLIC OF GEORGIA. Ad rivulos pr. Helenendorf, 1838, Hohenacker (W1889880289, W0227453, PRC452707, 452708, G-Boiss, isolectotypes); Prope pag. Karajazy, 21-5-1908, Leg. Koenig (W1940-22731, W1954-4398); Lagodechi Reserve, 41²4''25" N 4513'35" E, 15-6-1995, Leg. J. Gaskin (MO5568882, ut T. smyrnensis); East Georgia, Iori Table land, Vashlovani reserve, 25-5-2002, Leg. K. Ishagashvili, N. Lachashvili (W200906712, ut T. smyrnensis); East Georgia, Dedoplistskaro district, Iori plateau, Lekistskali

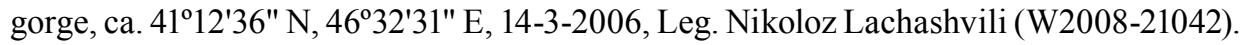
IRAN. South $7 \mathrm{~km}$ west of Dahst along Qez-qaleh valley, 18-5-1995, Leg. H. Akhani (W1999-07675, ut T. ramosissima). MEXICO. Baja California: Ensenada, Maniadero, Río San Salvador, 11R587235243, 803 m. 16-4-2010, Leg. J.L. Villar, M.A. Alonso, A. Juan (ABH57398). UNITED STATES OF AMERICA. Colorado: Mesa County, along frontage road to Interstate 70, at exit to DeBeque, $3^{\circ} 19^{\prime} 24^{\prime \prime} \mathrm{N}, 108^{\circ} 12^{\prime} 00^{\prime \prime} \mathrm{W}, 4919 \mathrm{ft}$, 2-6-2005, Leg. Robert M. King, Robert M. Garvey (MO04808092, ut T. parviflora). UZBEKISTAN: Tashkent, Bekabaddistrict, $40^{\circ} 31.82^{\prime}$ N-69 $5.00^{\prime}$ E, Leg. Igor Belolipov, Hislat Haydarov (MO6047301).

T. ramosissima. MEXICO: Baja California: Playas de San Felipe, 11RQQ010508 (3110'26,4" N-114'53'27,3" W), 0 m, 16-4-2010, Leg. J.L. Villar, M.A. Alonso (ABH57459); Mexicali, Laguna Salada, junto a carr. Tecate - Mexicali, 11SPS177042 (32³4'8,4" N-11544'46,1" W), 0 m, 18-4-2010, Leg. J.L. Villar, M.A. Alonso, A. Juan (ABH57462); Isla Ángel de la Guarda, East side of island, in middle of narrow dry arroyo, 29 $27^{\prime} 579^{\prime \prime} \mathrm{N}-113^{\circ} 24^{\prime} 830^{\prime \prime}$ W, 85 feet, 3-2006, Leg. P. García (BCMEX0013719); Mexicali, Lower Rio Colorado valley, 32 $13^{\circ} 48.4^{\prime \prime} \mathrm{N}-115^{\circ} 02^{\prime} 55.8^{\prime \prime} \mathrm{W}, 10 \mathrm{~m}, 17-3-2006$, Leg. Richard S. Felger, K, Reichhard, E. Soto-Montoya (BCMEX013156); Ensenada, Ctra Ensenada - San Felipe, 31 $10^{\prime} \mathrm{N}-115^{\circ} 19^{\prime} \mathrm{W}, 21-7-1980$, Leg. A. Díaz (BCMEX0010101, ut T. pentandra); La 
Annex. Continuation.

Bocana, 31 $33^{\prime}$ N-116 $10^{\prime}$ W, 30-9-1982, Leg. Ortiz, Arroyo, Mora (BCMEX005512, ut T. pentandra); Ensenada, Arroyo, zona adentrada a la presa, $31^{\circ} 53^{\prime} \mathrm{N}-116^{\circ} 35^{\prime} \mathrm{W}, 15-$ 6-1980, Leg. Gálvez, López, Héctor, Det. Gálvez (BCMEX000166, ut T. pentandra);

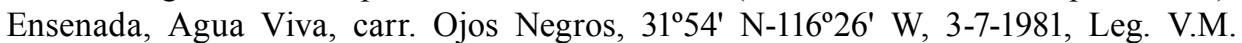
Preciado (BCMEX000119, ut T. pentandra); Ensenada, 31 ${ }^{\circ} 53^{\prime} \mathrm{N}-116^{\circ} 40^{\prime} \mathrm{W}, 21-7-1980$, Leg. L. Heredia (BCMEX000037, ut T. pentandra); Isla Cedros, Casa de Piedra del Gran Cañón, 28 $10^{\prime}$ N-115¹5' W, 50 m, 27-12-1986, Leg. Hugo Cota (BCMEX003223, ut T. pentandra); South of Santa Catarina, near coast south of Punta Canoas and Puerto Mujeres, Cañon Lázaro, 29²4'69" N-11502'22" W, 20-150 m, 17-4-1997, Leg. J. Rebman, J. Merzbacher, T. Demeré (BCMEX009904); Along the Ensenada to Tecate highway, about 28.5.miles north of Ensenada, near Predio Belen, North of Guadalupe, along cold water stream, 32 ${ }^{\circ} 11^{\prime} \mathrm{N}-116^{\circ} 29^{\prime} \mathrm{W}, 500 \mathrm{~m}$, Leg. R.F. Thorne, W. Wisura, W. Steinmetz (BCMEX001393); Sonora: Hermosillo, La Victoria, 2906'49.219" N-11052'17.786" W, 310 m, 25-5-1996, Leg. R. Palafox, Det. O.J. Soto (BCMEX003545, ut T. pentandra).

T. smyrnensis. CYPRUS. Cap Arnaouk, près polis, Leg. M. Haradjian (MO1621122); Ad alveos prope litora maris in viciniis Kuklia Amathus et aliis locis, 5-1862, Leg. Kotschy (W, G-Boiss). GREECE. Rhodes. Bords des torrents près Salakos, 31-5-1870, Leg. Bourgeau (W1889-150434, G-Boiss); Ad ripas Penes prope Larissam, 2-8-1882, Leg. Heldreich (G); Etolias-Akaranias, Mesolongui, coast by the salt works, c. $5 \mathrm{~km} \mathrm{NW}$ of Mesolongi, clayey marsh, 9-6-1997, Leg. Nielsen (G). TURKEY. In arenosis humidis Smyrnae, april-majo 1827, Leg. Fleischer (W1889-320298, PRC452718, PRC452719, PRC452720 isotypes); Smyrne, Leg. Monbret (W1889-223513); Marais d'eau saumatre situès entre la Papeterie et la mer, près de Smyrne, 1854, Leg. Balansa (MO5475118, W1889-81992, W1889-80859); C4 Icel. 12 km S Mut, 200 m, 6-6-1966, Leg. F. Sorger (W1990-07003); Pamukkale E C2 Denizli, 400 m, 28-6-1967, Leg. F. Sorger (W199006983); Gök Pinar. B6 Sivas, 1600 m, 9-9-1977, Leg. F. Sorger (W1990-06992); 4 km S Uluabat, Damm A2 Bursa, 27-6-1977, Leg. F. Sorger (W1990-06989). 